\section{HPV detection in the oral and genital mucosa of women with positive histopathological exam for genital HPV, by means of the PCR}

\author{
Therezita M. Peixoto Patury Galvão Castro ${ }^{1}$, \\ Ivo Bussoloti Filbo ${ }^{2}$, Velber Xavier Nascimento ${ }^{3}$, \\ Sandra Doria Xavier ${ }^{4}$
}

\section{Summary}

\begin{abstract}
$\mathrm{I}_{\mathrm{r}}$ Infection by the Human Papilloma Virus (HPV) is one of the most frequent sexually transmitted diseases all over the world. The relationship between oral and genital HPV remains uncertain, as it is with its role on oral carcinogenesis. The goal of the present investigation was to check for the presence of HPV DNA in the oral and genital mucosas of women with HPV genital infection, using the polymerase chain reaction (PCR). Study method: Cross-sectional cohort. Materials and Methods: this is a pilot and prospective study involving 30 women, aged between 14 and 51 years, with HPV genital infection, confirmed by histopathology. All the patients were submitted to the exam and sample collection by swabbing the oral and genital mucosas in order to test for HPV DNA through the PCR technique. Results: none of the oral cavity samples were positive for HPV, while in the genital tract, HPV was detected in 17 (57\%) of the 30 patients, especially HPVs 6b and 16. Conclusion: Results show a higher percentage of genital HPV in comparison to the oral cavity, and suggest that genital HPV does not seem to be a predisposing factor for the oral infection in the same patient.
\end{abstract}

${ }^{1}$ Master's degree in medicine, Faculdade de Ciências Médicas da Santa Casa de São Paulo. Graduate doctoral student, Faculdade de Ciências Médicas da Santa Casa de São Paulo.

${ }^{2}$ Doctorate in medicine, UNIFESP. Adjunct professor of Otorhinolaryngology, Faculdade de Ciências Médicas da Santa Casa de São Paulo, FCMSCSP. ${ }^{3}$ Graduate doctoral student in molecular biology

Master's degree in Otorhinolaryngology, Faculdade de Ciências Médicas da Santa Casa de São Paulo. Presented in the 5th Congresso Triológico de Otorrinolaringologia, in Brasilia (6 to 9 June 2007).

Address for correspondence: Therezita P. Galvão - Fax: (0xx82)3327-5353 - E-mail: therezitagalvao@bol.com.br This paper was submitted to the RBORL-SGP (Publishing Manager System) on 30 August 2007. Code 4755.

The article was accepted on 1 February 2008. 


\section{INTRODUCTION}

The human papillomavirus (HPV) belongs to a heterogeneous ${ }^{1}$ group of DNA viruses that infect the skin and mucosae in various sites of the human body. ${ }^{2}$

The transmission mode of this virus to the oral mucosa is not clearly known. It has been suggested that transmission may occur during vaginal birth, self-inoculation, or oral sex..$^{3-5}$

It appears that saliva has a protective role against HPV infection due to the presence of antimicrobial agents such as lysozymes, lactoferrin, IgA and cytokines. ${ }^{6,7}$

The most frequently affected sited in the mouth are the lips, palate, tongue, gingiva, uvula, tonsils, and the floor of the mouth. Saliva accumulates on the floor of the mouth; cancerous agents dissolved in saliva, such as tobacco and alcohol, provide ample opportunity for harmful viral activity. 8,9

HPV infection has classically been divided into three separate manifestations: clinical, subclinical and latent for$\mathrm{ms}$. Clinical infection is easily detected with the naked eye, in the form of a wart. The subclinical form occurs more frequently on the cervix ( $80 \%$ of cases) and is diagnosed by colposcopy after applying 5\% acetic acid. The latent form is diagnosed only by molecular biological tests. ${ }^{10,11}$

Biopsies are used to study the pathology of a specimen and to grade the disease. Molecular biological tests are required for diagnosing HPV and defining its type. ${ }^{12}$

Hybridization tests of tissue samples and smears are currently the methods of choice for detecting the HPV DNA. These methods include the dot blot, the Southern blot, in situ hybridization, and the polymerase chain reaction $(\mathrm{PCR})$; the latter is the most sensitive of these tests. ${ }^{13,14}$

The PCR increases - by many million times - minute amounts of target DNA sequences. Initiating systems (primers) are used, the most common being the MY09-MY11 and the GP5-GP6 primer systems. ${ }^{15-17}$

HPV types vary according to their tissue tropism, their associations with different lesions and their oncogenic potential. These types may be characterized as low risk HPVs for developing malignancies (types 6, 11, 41, 43, 44) and high risk HPVs for developing malignancies $(16,18,31,33,35,39,45,46,51,52)$. Types 6 and 11 are the two main types involved in most of the genital warts (condylomas); types 16 and 18 are found mainly in cervical cancer. ${ }^{12,16,17}$

Over $100 \mathrm{HPV}$ types have been found to date.1820 Of these, 25 types (HPV-1, 2, 3, 4, 6, 7, 10, 11, 13, 16, $18,31,32,33,35,40,45,52,55,57,58,59,69,72$ and 73 ) have been associated with benign oral lesions (squamous cell papilloma), condylomata acuminata, common warts, focal epithelial hyperplasia, and malignancies such as the squamous cell carcinoma. ${ }^{21}$
Many researchers have studied oral and genital HPV to discover whether genital infection by this virus could lead to infection elsewhere, such as in the mouth. ${ }^{22-26}$

Van Doornum et al. ${ }^{22}$ (1992) applied the PCR to study oral and genital HPV in 65 males and 111 females. Examination of the mouth consisted of unaided visual inspection and scrapes for further study. Genital HPV was found in $21(32 \%)$ of 65 males and $25(23 \%)$ of 111 females; none of these patients had oral HPV. There were no reports of oral sex.

Badarrocco et al. ${ }^{23}$ (1998) applied the PCR and found oral HPV in five of ten women diagnosed with genital HPV. Unaided visual inspection of the mouth and colposcopy was don in all patients; oral scrapes were taken. There were no reports of oral sex.

Camadas et al. ${ }^{24}$ (2004) applied the PCR to study genital and oral HPV in 188 females. Unaided visual inspection was done of the mouth and scrapes were made. The positivity rate in the mouth was 15 (7.9\%). There were no reports of oral sex.

Giraldo et al. ${ }^{25}$ (2006) found positive HPV PCR testing in $29(20.7 \%)$ of 140 females with or with no genital lesions. Scrapes were taken from the oral mucosa in which unaided visual inspection had been carried out. These authors also highlighted that genital HPV was present in 26 (89\%) of 29 females with oral HPV, as detected by the PCR. Oral sex was practiced by $16(55.2 \%)$ of 29 women with positive oral HPV, and by 59 (23.2\%) of 111 women that tested negative for oral HPV.

Xavier et al.26 (2007) applied the PCR to test 10 males with PCR-confirmed genital HPV for oral HPV. Unaided visual inspection was done of the mouth and scrapes were made. None of these patients had the HPV in the oral mucosa; there were no reports of oral sex.

Further investigation is required on this theme, considering the conflicting results described in the literature about the presence and relation of oral HPV with genital HPV.

The purpose of this study was to verify the presence of HPV DNA in the oral and genital mucosa of patients with genital HPV infection by applying the PCR technique.

\section{MATERIAL AND METHOD}

A retrospective study was done from May 2005 to November 2006. The Research Ethics Committee of the UFAL approved the study (protocol number 005564/02-50). All patients were informed about the purpose of the study and the required procedures if participating. All of them read and signed a free informed consent form.

The inclusion criteria were sexually active female subjects aged from 14 to 51 years that presented clinical or subclinical genital HPV. Exclusion criteria were patients with immunological conditions, such as HIV infection, 
immunosuppressed patients, and users of immunosuppressant drugs.

Thirty patients with genital warts (clinical and/or subclinical) suggesting HPV infection were recruited. All subjects underwent a gynecological exam, colposcopy (with 5\% acetic acid), and biopsies of warts for diagnosis. Scrapes for cytology using sterilized brushes (colpocytology kits, Libbs ${ }^{\circledR)}$ were taken from genital lesion sites (external genital, vagina and cervix) during colposcopy.

On the same day, unaided visual inspection was made of the oral cavity, using artificial light (photophore) in an attempt to identify any clinical lesion that might suggest HPV infection. Samples were taken from sites where the HPV was likely to be found by scraping the oral mucosa with sterilized brushes (the soft palate, the uvula, the tonsils, dorsum of tongue, the sublingual area, and the jugal mucosa. Examination of the mouth did not include use of a colposcopy or application of acetic acid.

The scrapes were placed in separate vials containing a buffer solution (tris-HCL 10mM, pH 8, EDTA 1mM ) and identified as either genital or oral; the vials were sent to the Molecular Biology Laboratory of the Universidade Federal de Alagoas (UFAL) and stored at $-20^{\circ} \mathrm{C}$ for testing with the PCR technique.

Extraction of genomic DNA was done using the GFX kit (Asmersham Bioscience) method; the DNA concentration in each sample was estimated using a spectrophotometer (Genova). The MY09/MY11 primer systems were used for viral DNA amplification; viral types were identified according to their electrophoretic patterns.

Subjects also answered a standard questionnaire on epidemiological issues, such as the beginning of sexual life, the number of partners, oral sex, use of alcohol and smoking.

\section{RESULTS}

The epidemiological survey revealed that 22 of 30 patients (73\%) engaged in oral sex, and 16 patients $(53 \%)$ engaged in anal sex; nine patients (30\%) were smokers and none consumed alcoholic beverages; Table 1 presents these results.

The results of colposcopy showed subclinical lesions in 19 patients (63\%) of, subclinical lesions in eight patients (27\%), and clinical lesions in three patients (10\%), located mostly on the cervix. All 30 samples of genital lesions were positive for HPV. Table 1 shows these results.

The results of PCR testing of genital samples were positive in 17 cases (57\%) of the 30 patients; 13 cases had negative samples. The most frequent HPV type was the 6b type, found in seven (41\%) of the 17 positive samples, followed by type 16 in four samples (23\%). Types HPV66, HPV52, and HPV31 were found in one sample each (6\%). The type could not be determined in three samples (18\%).
Table 1 shows these results.

Unaided visual inspection of the mouth of 30 subjects revealed no clinical lesions suggesting HPV.

PCR test results in 30 samples of oral scrapings were HPV negative.

\section{DISCUSSION}

In this study 19 (63\%) of 30 patients had only subclinical genital HPV infection, mostly in the cervix, which was confirmed by colposcopy. This is similar to other published studies, showing that this is the most frequent HPV infection. ${ }^{10,11}$

Histology is an important method for diagnosing HPV infection; all of the genital samples had histological changes that suggested this diagnosis. This may be considered as a routine first exam for the diagnosis of HPV infection. However, since histology is unable to identify the HPV, molecular biology techniques are needed for confirming HPV infection;12 this is done mostly using PCR techniques, which is more sensitive for detecting the HPV. ${ }^{13,14}$

The PCR technique was the method we chose to identify oral and genital HPV in this study; we used the MY09-MY11 primer systems,16-18 which is the most sensitive $^{13,14}$ and preferred method for detecting HPV DNA in tissue smears and samples. ${ }^{14}$

The most frequent HPV types found in the genital area of 17 patients that were PCR-positive for HPV were the types $6 \mathrm{~b}(41 \%)$ and 16 (23\%). The former is a low-risk type and is frequently found in genital condylomas; the latter is found mainly in cervical cancer. ${ }^{17}$

The number of smokers in the 30-patient sample was nine (30\%); none of them consumed alcoholic beverages. These variables did not affect the results, although they are factors that favor HPV infection in the mouth. ${ }^{8,9}$

The samples of the mouth were PCR-negative in all 30 patients of this study. In other studyes ${ }^{22-26}$ that used the same technique, the positivity rate ranged from 0 to $50 \%$. We concluded that the presence of genital HPV infection does not appear to be a predisposing factor for oral HPV infection. This result is important for patients with genital HPV infection who become worried about possible transmission of the disease to their partner(s) and to other bodily sites.

Low immunological defense is probably the most important factor for HPV infection in other sites of the body. The mouth contains IgA and proteolytic enzymes that protect against HPV infection. ${ }^{6,7}$

HPV transmission to the mouth is not yet clearly understood..$^{3-5}$ The rate of oral sex was high in our sample; however, the results of oral HPV infection were negative in $73 \%$ of cases. Compared with other studies, ${ }^{22-26}$ we found that few patients were aware of this transmission mode to 
Table 1. Individual results of the 30 subjects in this study

\begin{tabular}{|c|c|c|c|c|c|c|c|c|c|c|}
\hline $\mathrm{N}$ & Age & $\begin{array}{l}\text { Genital } \\
\text { lesion }\end{array}$ & Site & HPV type & Histological diagnosis & $\begin{array}{l}\text { Beginning } \\
\text { of sexual } \\
\text { activity }\end{array}$ & $\begin{array}{l}\text { Number } \\
\text { of sexual } \\
\text { partners }\end{array}$ & $\begin{array}{l}\text { Oral } \\
\text { sex }\end{array}$ & $\begin{array}{l}\text { Anal } \\
\text { sex }\end{array}$ & Smoking \\
\hline 1 & 32 & subclinical & cervix & 16 & SIL high grade & 17 & 3 & no & no & no \\
\hline 2 & 30 & subclinical & Cervix & 16 & Alt. suggest. HPV & 17 & 4 & yes & yes & yes \\
\hline 3 & 36 & $\begin{array}{l}\text { Clinical / } \\
\text { subclinical }\end{array}$ & Cervix / vulva & $6 b$ & SIL low grade & 17 & 2 & yes & yes & no \\
\hline 4 & 19 & subclinical & cervix & - & Alt. suggest. HPV & 13 & 1 & yes & no & no \\
\hline 5 & 24 & subclinical & cervix & In. & SIL low grade & 22 & 1 & no & no & no \\
\hline 6 & 29 & subclinical & Cervix ,vagina & - & Alt. suggest. HPV & 19 & 4 & yes & yes & no \\
\hline 7 & 39 & subclinical & cervix & - & SIL low grade & 17 & 5 & yes & no & no \\
\hline 8 & 21 & Clinical & $\begin{array}{l}\text { Cervix, vulva } \\
\text { vagina }\end{array}$ & $6 b$ & condyloma & 20 & 1 & no & no & no \\
\hline 9 & 15 & $\begin{array}{l}\text { Clinical / } \\
\text { subclinical }\end{array}$ & Cervix / vulva & - & Alt. suggest. HPV & 14 & 1 & yes & no & no \\
\hline 10 & 21 & subclinical & cervix & - & SIL low grade & 18 & 5 & yes & yes & no \\
\hline 11 & 51 & subclinical & cervix & 66 & SIL low grade & 22 & 3 & yes & yes & no \\
\hline 12 & 42 & subclinical & cervix & - & Alt. suggest. HPV & 15 & 2 & yes & yes & yes \\
\hline 13 & 21 & $\begin{array}{c}\text { Clinical / } \\
\text { subclinical }\end{array}$ & $\begin{array}{l}\text { Cervix, vulva, } \\
\text { vagina }\end{array}$ & $6 b$ & SIL low grade & 16 & 2 & yes & yes & yes \\
\hline 14 & 19 & subclinical & Vulva, vagina & - & Alt. suggest. HPV & 15 & 2 & yes & yes & yes \\
\hline 15 & 17 & $\begin{array}{l}\text { Clinical / } \\
\text { subclinical }\end{array}$ & Cervix, vulva & $6 b$ & condyloma & 12 & 2 & yes & no & no \\
\hline 16 & 36 & subclinical & cervix & - & Alt. suggest. HPV & 18 & 2 & yes & no & yes \\
\hline 17 & 25 & subclinical & cervix & 16 e MM8 & SIL low grade & 13 & 3 & yes & no & no \\
\hline 18 & 32 & subclinical & vagina & - & Alt. suggest. HPV & 15 & 6 & yes & yes & no \\
\hline 19 & 45 & Clinical & Vulva, anus & $6 b$ & condyloma & 19 & 4 & yes & yes & yes \\
\hline 20 & 32 & subclinical & cervix & In. & SIL low grade & 17 & 1 & no & no & yes \\
\hline 21 & 19 & subclinical & Cervix, vagina & - & SIL low grade & 15 & 3 & yes & yes & no \\
\hline 22 & 14 & $\begin{array}{l}\text { Clinical / } \\
\text { subclinical }\end{array}$ & $\begin{array}{l}\text { Cervix,vulva, } \\
\text { vagina }\end{array}$ & 16 & SIL high grade & 14 & 1 & yes & yes & no \\
\hline 23 & 32 & subclinical & cervix & 31 & SIL low grade & 16 & 2 & yes & yes & no \\
\hline 24 & 21 & $\begin{array}{l}\text { Clinical / } \\
\text { subclinical }\end{array}$ & Cervix, vulva & $6 b$ & Alt. suggest. HPV & 15 & 2 & yes & yes & no \\
\hline 25 & 24 & subclinical & cervix & $6 b$ & SIL low grade & 15 & 1 & yes & yes & no \\
\hline 26 & 16 & $\begin{array}{l}\text { Clinical / } \\
\text { subclinical }\end{array}$ & $\begin{array}{l}\text { Cervix, vulva / } \\
\text { vagina }\end{array}$ & - & Alt. suggest. HPV & 13 & 4 & yes & yes & yes \\
\hline 27 & 32 & subclinical & Cervix & 52 & SIL low grade & 15 & 1 & no & no & no \\
\hline 28 & 36 & $\begin{array}{l}\text { Clinical / } \\
\text { subclinical }\end{array}$ & $\begin{array}{c}\text { Cervix, vulva / } \\
\text { vagina }\end{array}$ & - & Alt. suggest. HPV & 28 & 2 & no & no & no \\
\hline 29 & 34 & Clinical & vagina & In. & Alt. suggest. HPV & 18 & 1 & no & no & no \\
\hline 30 & 32 & subclinical & cervix & - & SIL high grade & 22 & 2 & no & no & no \\
\hline
\end{tabular}

$\mathrm{HPV}=$ human papilloma virus; In=Indeterminate; $\mathrm{SIL}=$ Squamous intraepithelial lesions 
the mouth; it was thus impossible to conclude whether patients with genital lesions that engaged in oral sex were more predisposed to have oral HPV infection.

Further studies are needed on the relation between oral and genital HPV infection to explain its action on the oral mucosa.

\section{CONCLUSION}

In this study, the percentage of HPV infection was higher in the genital area (57\%) compared to the oral mucosa (0\%); this suggests that genital HPV is not a predisposing factor for oral HPV infection in the same patient.

\section{REFERENCES}

1. De Villiers E. Heterogeneity of the Papillomavirus Group. J Virol. 1989;3:4898-903.

2. Chang F, Syrjanen S, Kellokoski J, Syrjänen K. Human papillomavirus (HPV) infections and their associations with oral disease. J Oral Pathol Med. 1991;20:305-17.

3. Fredericks BD, Balklin A, Daniel HW, Schonrock J, Ward B, Frazer IH. Transmission of Human Papillomaviruses from Mother to Child. J Obstet Gynaecol. 1993;33:1-30.

4. Giraldo PC, Simões JA, Ribeiro Filho DA, Tambascia JK, Dias AL, Pacello PC. Avaliação citológica da Orofaringe de Mulheres portadoras de HPV Genital. Rev Bras Ginecol Obstet. 1996;18(9):737-42.

5. Zur Hausen H. Papillomavirus infections - a major cause of human cancers. BBA 1996;1288:55-78.

6. Kellokoski J, Syrjänen S, Yliskoki M, Syrjanen K. Dot blot hybridization in detection of human papillomavirus (HPV) infections in the oral cavity of women with genital HPV infections. Oral Microbiol Immunol. 1992;7:19-23.

7. Miletic ID, Schiffman SS, Milectic VD, Satterly-Miller EA. Salivary IGA secretion rate in young and elderly persons. Physiop Behav. 1996;60:243-8.

8. Terai M, Takagi M, Matsukura T, Sata T. Oral wart associated with human papillomaviruses type 2. J Oral Pathol Med. 1999:28:137-40.

9. Marone SA, Gusmão RJ. HPV em outras especialidades, epidemiologia, diagnóstico e tratamento. In: Carvalho JM, Oyakawa N. 1a Consenso Brasileiro do HPV. São Paulo: Editora BG Cultural; 2000.p.87-95.

10. Pereyra EA, Tacla M. HPV na mulher - Colposcopia. In: Carvalho JM, Oyakawa N. 1롤 Consenso Brasileiro do HPV. São Paulo: Editora BG Cultural;2000.p.17-34.

11. Carvalho JJM. Papilomavírus humano. In: Carvalho JJM. Manual prático do HPV: papilomavírus humano. São Paulo: Instituto Garnet; 2004.p. 13-4.
12. Camargos AF, Hugo de Melo V. Doenças sexualmente transmissíveis. In: Camargos AF, Hugo de Melo V. Ginecologia ambulatorial. Belo Horizonte: editora Coopamed; 2001. p. 397-400.

13. Syrjänen $S$. Cavidade oral e trato respiratório superior: diagnóstico e tratamento. In Gross GE, Barrasso R. Infecção por papilomavírus humano: Atlas clínico de HPV, $2^{\underline{a}}$ ed. Porto Alegre: Editora Artes Médicas; 1999.p.399-409.

14. Zahm DM, Nindl I, Schneider A. Princípios gerais do diagnóstico: detecção do papilomavírus humano. In Gross GE, Barrasso R. Infecção por papilomavírus humano: Atlas clínico de HPV, 20 ed. Porto Alegre: Editora Artes Médicas; 1999.p.21-45.

15. Gravitt PE, Peyton CL, Alessi TQ, Wheeler CM, Coutlée F, Hildesheim A, et al. Improved amplification of genital human papillomaviruses. J Clin Microbiol. 2000;38:357-61.

16. Ribeiro KM. Estudo da ocorrência do Papilomavírus humano em tonsilas palatinas na população pediátrica. Tese (Mestrado). São Paulo: Escola Paulista de Medicina; 2002.

17. Galvão TM. Prevalência do papilomavírus humano (HPV) na cavidade oral e na orofaringe. Tese (mestrado). São Paulo: Faculdade de Ciências Médicas da Santa Casa de São Paulo; 2004.

18. Bouda M, Gorgoulis VG, Kastrinakis NG, Giannoudis A, Tsoli E, Danassi-Afentaki D et al. "High risk" HPV types are frequently detected in potentially malignant and malignant oral lesions, but not in normal oral mucosa. Mod Pathol. 2000;13(6):644-53.

19. Terai M, Takagi M. Human Papillomavirus in Oral Cavity. Oral Med Pathol. 2001;6:1-12.

20. Kojima A, Maeda H, Sugita Y, Tanaka S, Kameyama Y. Human papillomavirus type 38 infection in oral squamous cell carcinomas. Oral Oncology. 2001;38:591-96.

21. Syrjänen S. Human papillomavirus infections and oral tumors. Med microbiol Immunol. 2003;192:123-8.

22. Van Doornum GJ, Hooyfaas C, Juffermasns L, Van Der Lans S, Van Der Linden M, Coutnho R. Prevalence of human papillomavirus infections among heterosexual men and women with multiple sexual partners. J Med Virol. 1992;37:13-21.

23. Badaracco G, Venuti A, Di Lonardo A, Scambia G, Mozzetti S, Panici $\mathrm{PB}$, et al. Concurrent HPV infection in oral and genital mucosa. J Oral Pathol Med. 1998;27:130-4.

24. Canadas MP, Bosch XF, Junquera ML, Ejarque M, Font R, Ordonez E, et al. Concordance of prevalence of human papillomavirus DNA in anogenital and oral infections in a high-risk population. J Clin Microbiol. 2004;42(3):1330-2.

25. Giraldo P, Gonçalves A, Pereira S, Barrosos-Mazon S, Gondo M, Witkin S. Human papillomavirus in the oral mucosa of women with genital human papillomavirus lesions. Eur J Obstet Gynecol Reprod Biol. 2006;126:104-6.

26. Xavier SD, Bussoloti Filho I, Carvalho JM, Framil VM, Castro TM. Freqüência de aparecimento de Papilomavírus Humano na mucosa oral de homens com HPV anogenital confirmado por biologia molecular. Arq Int Otorrinolaringol. 2007;11(1):36-44. 